University of Wollongong

Research Online

Faculty of Science, Medicine and Health -

Papers: Part B

Faculty of Science, Medicine and Health

$1-1-2019$

(R)-3-(8'-Hydroxyfarnesyl)-indole and other chemical constituents from the flowers of Anomianthus dulcis and their antimalarial and cytotoxic activities

\author{
Thanika Promchai \\ Chiang Mai University \\ Thanaphat Thaima \\ University of Wollongong, thaima@uow.edu.au \\ Roonglawan Rattanajak \\ National Science and Technology Development Agency, Thailand, BIOTEC, Pathum Thani 12120, Thailand \\ Sumalee Kamchonwongpaisan \\ National Science and Technology Development Agency, Thailand, BIOTEC, Pathum Thani 12120, Thailand \\ Stephen G. Pyne \\ University of Wollongong, spyne@uow.edu.au
}

See next page for additional authors

Follow this and additional works at: https://ro.uow.edu.au/smhpapers1

Publication Details Citation

Promchai, T., Thaima, T., Rattanajak, R., Kamchonwongpaisan, S., Pyne, S. G., \& Limtharakul, T. (2019).

(R)-3-(8'-Hydroxyfarnesyl)-indole and other chemical constituents from the flowers of Anomianthus dulcis and their antimalarial and cytotoxic activities. Faculty of Science, Medicine and Health - Papers: Part B.

Retrieved from https://ro.uow.edu.au/smhpapers1/1099

Research Online is the open access institutional repository for the University of Wollongong. For further information contact the UOW Library: research-pubs@uow.edu.au 


\title{
(R)-3-(8'-Hydroxyfarnesyl)-indole and other chemical constituents from the flowers of Anomianthus dulcis and their antimalarial and cytotoxic activities
}

\author{
Abstract \\ A new farnesylindole, (R)-3-(8'-hydroxyfarnesyl)-indole (1), as a scalemic mixture (33\% ee) along with nine \\ known compounds (2-10), including one farnesylindole, three flavanones, three flavone derivatives and \\ two chalcone derivatives were isolated from the methanolic crude extract of the flowers from \\ Anomianthus dulcis. All compounds were purified by appropriate chromatographic techniques and their \\ structures elucidated by spectroscopic methods. Compounds 1, 2 and 8 showed moderate \\ antiplasmodial activities against TM4/8. Two and K1CB1 strains of which compound 2 displayed the best \\ activity with IC50 values of $27.9 \pm 2.57$ and $21.4 \pm 1.68 \mu \mathrm{M}$, respectively. In addition, compound 1 also \\ presented modest cytotoxicity against a KB cell line with an IC50 value of $22.3 \pm 0.39 \mu \mathrm{M}$. None of these \\ compounds showed cytotoxicity against Vero cells.

\section{Publication Details} \\ Promchai, T., Thaima, T., Rattanajak, R., Kamchonwongpaisan, S., Pyne, S. G. \& Limtharakul, T. (2019). \\ (R)-3-(8'-Hydroxyfarnesyl)-indole and other chemical constituents from the flowers of Anomianthus dulcis \\ and their antimalarial and cytotoxic activities. Natural Product Research

\section{Authors} \\ Thanika Promchai, Thanaphat Thaima, Roonglawan Rattanajak, Sumalee Kamchonwongpaisan, Stephen \\ G. Pyne, and Thunwadee Limtharakul
}




\section{(R)-3-(8'-Hydroxyfarnesyl)-indole and other chemical constituents}

from the flowers of Anomianthus dulcis and their antimalarial and cytotoxic activities

Thanika Promchai ${ }^{\mathrm{a}, \mathrm{b}, \mathrm{c}}$, Thanaphat Thaima ${ }^{\mathrm{c}}$, Roonglawan Rattanajak ${ }^{\mathrm{d}}$, Sumalee Kamchonwongpaisan ${ }^{\mathrm{d}}$, Stephen G. Pyne ${ }^{\mathrm{c}}$ and Thunwadee Limtharakul ${ }^{\mathrm{a}, \mathrm{e}}$

${ }^{a}$ Department of Chemistry and Center of Excellence for Innovation in Chemistry, Faculty of

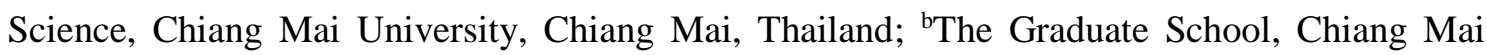
University, Chiang Mai, Thailand; 'School of Chemistry and Molecular Bioscience, University of Wollongong, Wollongong, NSW, Australia; ${ }^{\mathrm{d}}$ Medical Molecular Biology Research Unit, Natural Center for Genetic Engineering and Biotechnology, National Science and Technology

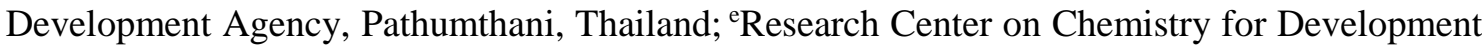
of Health Promoting Products from Northern Resources, Chiang Mai University, Chiang Mai, Thailand.

Contact: Thunwadee Limtharakul,e-mail address: thunwadee.r@cmu.ac.th 


\title{
(R)-3-(8'-Hydroxyfarnesyl)-indole and other chemical constituents from the flowers of Anomianthus dulcis and their antimalarial and cytotoxic activities
}

\begin{abstract}
A new farnesylindole, $(R)$-3-(8'-hydroxyfarnesyl)-indole (1), as a scalemic mixture (33 $\% e e$ ) along with nine known compounds (2-10), including one farnesylindole, three flavanones, three flavone derivatives and two chalcone derivatives were isolated from the methanolic crude extract of the flowers from Anomianthus dulcis. All compounds were purified by appropriate chromatographic techniques and their structures elucidated by spectroscopic methods. Compounds $\mathbf{1}, \mathbf{2}$ and $\mathbf{8}$ showed moderate antiplasmodial activities against TM4/8.2 and K1CB1 strains of which compound 2 displayed the best activity with $\mathrm{IC}_{50}$ values of $27.9 \pm 2.57$ and $21.4 \pm 1.68 \mu \mathrm{M}$, respectively. In addition, compound $\mathbf{1}$ also presented modest cytotoxicity against a $\mathrm{KB}$ cell line with an $\mathrm{IC}_{50}$ value of $22.3 \pm 0.39 \mu \mathrm{M}$. None of these compounds showed cytotoxicity against Vero cells.
\end{abstract}

Keywords: Anomianthus dulcis; farnesylindole; antiplasmodial activities; cytotoxicity

\section{Introduction}

Anomianthus dulcis (synonym Uvaria dulcis or "Nom Maew Son" in Thai) belongs to the Annonaceae family which are distributed in Northeastern and Southern of Thailand (Smitinand T. 2014). The water decoction of the stem and roots of this plant has been used for fever treatment and as a galactagogue in traditional medicine (Sapchareun P. 2006). The chemical constituents of the twigs, stems and leaves have been identified as polyoxygenated cyclohexenes (Kaweetripob et al. 2015), acetogenins (Sinz et al. 1998a) phenylpropanoid amides (Sinz et al. 1999), flavonoids (Chantrapromma et al. 2001; Ubonopas et al. 2014) and alkaloids (Sinz et al. 1998b; Ubonopas et al. 2014). The crude extract and some secondary metabolites from this plant showed antibacterial (Ubonopas et al. 2014; Kadchumsang et al. 2015), anticancer, anti-Herpes Simplex Virus I (Ubonopas et al. 2014), antispasmodic, (Wiya et al. 2018) and antioxidant activities (Kadchumsang et al. 2015). Furthermore, previous investigations of plants from the Uvaria genus have found several types of secondary metabolites such as polyoxygenated cyclohexenes (Ho et al. 2015; Okpekon et al. 2015; Hsu et al. 2016; Auranwiwat et al. 
2017; Awale et al. 2017; Auranwiwat et al. 2019a; Auranwiwat et al. 2019b), flavonoids (Salae et al. 2017; Auranwiwat et al. 2018), alkaloids (Auranwiwat et al. 2018), naphthalenes (Auranwiwat et al. 2017; Salae et al. 2017), xanthenes (Macabeo et al. 2014) and lignan glycosides (Nguyen et al. 2015). Some of these chemical constituents have shown significant bioactivities, including anticancer (Macabeo et al. 2014; Ho et al. 2015; Awale et al. 2017), anti-inflammatory (Hsu et al. 2016), antimalarial (Auranwiwat et al. 2017; Salae et al. 2017), antimicrobial (Okpekon et al. 2015), antiglycation and antioxidant activities (Thomas and Essien 2018). The crude extract of $U$. angolensis inhibited HIV-1 RNase H function and RDDP activity (Mfopa et al. 2017). Herein, we report on the phytochemicals from the flower extracts of A. dulcis and their antimalarial activities and cytotoxicities.

\section{Results and discussion}

The dried flowers of $A$. dulcis were extracted with methanol and the crude extract was separated using various chromatographic techniques which led to the isolation of a new indole alkaloid, $(R)-3$-(8'-hydroxyfarnesyl)-indole (1), and nine known compounds; 3farnesylindole (2) (Nkunya et al. 1987), ( \pm )-pinostrobin (3) (Chou et al. 2010), (+)dihydrowogonin (4) (McNulty et al. 2009), (-)-pinocembrin (5) (Liu et al. 2016), chrysin (6) (Benabderrahmane et al. 2018), 2',3',4',5',6'-pentahydroxychalcone (7) (Xia et al. 2010), luteolin (8) (Jung et al. 2004), 5-O-caffeoylshikimic acid (9) (Wada et al. 1988) and kaempferol-3- $\beta$-D-(6-O-trans-p-coumaroyl)glucopyranoside (10) (Tsukamoto et al. 2004) as shown in Figure 1. The structures of these compounds were determined by spectroscopic methods, including 1D and 2D NMR spectroscopy, UV-vis spectrophotometry, IR and mass spectrometry.

Compound $1\left\{[\alpha]_{D}^{27}-6.9\left(c \quad 0.15, \mathrm{CH}_{2} \mathrm{Cl}_{2}\right)\right\}$ was obtained as a yellow gum with a molecular formula of $\mathrm{C}_{23} \mathrm{H}_{31} \mathrm{NO}$ from the HRESI-MS ion peak at $m / z 360.2313[\mathrm{M}+\mathrm{Na}]^{+}$ (calculated for $\mathrm{C}_{23} \mathrm{H}_{31} \mathrm{NONa}, 360.2303$ ) which indicated an oxygenated derivative of 2 . The UV spectrum showed maximum absorption bands at $\lambda_{\max } 222$ and $283 \mathrm{~nm}$ which corresponded to an indole derivative (Sangster et al. 1964). The IR spectrum showed stretching bands for a hydroxy group at $3415 \mathrm{~cm}^{-1}$ and an alkene $\mathrm{C}=\mathrm{C}$ at $1617 \mathrm{~cm}^{-1}$. The former IR band indicated $\mathbf{1}$ was a hydroxy derivative of $\mathbf{2}$. The ${ }^{1} \mathrm{H}$ NMR spectrum of compound 1 (Table S2) showed resonances similar to those of 3-farnesylindole (2), 
except that one of the allylic methylene resonances in compound 2 was replaced by that of an oxymethine $\left(\delta_{\mathrm{H}} 3.97\right)$ resonance. Compared to compound 2, the C-6' olefinic proton resonance in compound $1\left(\delta_{\mathrm{H}} 5.41\right)$ was observed at lower field $\left(\delta_{\mathrm{H}} 5.14\right.$ in 2$)$ indicating the presence of a nearby hydroxy group substituent. The hydroxy group was attached at C-8' $\left(\delta_{\mathrm{c}} 77.4\right)$ from the HMBC correlations of H-8' $\left(\delta_{\mathrm{H}} 3.97\right)$ to C-6' $\left(\delta_{\mathrm{c}} 126.2\right), \mathrm{C}-7^{\prime}\left(\delta_{\mathrm{c}}\right.$ $136.9), \mathrm{C}^{-} 7^{\prime} \mathrm{CH}_{3}\left(\delta_{\mathrm{c}} 11.8\right), \mathrm{C}-9^{\prime}\left(\delta_{\mathrm{c}} 34.3\right)$ and $\mathrm{C}-10^{\prime}\left(\delta_{\mathrm{c}} 120.3\right)$. The configuration at $\mathrm{C}-8^{\prime}$ was designated based on an analysis of its Mosher ester derivatives (Ohtani et al. 1991). Compound 1 was reacted with the Mosher reagents; $(R)-(-)-\mathrm{MTPA}-\mathrm{Cl}$ and $(S)-(+)-$ MTPA-Cl which gave the $(S)$-MTPA (1a) and $(R)$-MTPA (1b) esters, respectively. These reactions produced a 2:1 and 1:2 mixture of diastereomeric ester derivatives indicating that 1 was a scalemic mixture of $33 \%$ ee. The ${ }^{1} \mathrm{H}$ NMR chemical shift differences $\left(\Delta \delta^{S R}\right)$ of $\mathrm{H}-2$ ', H-6', $\mathrm{H}_{\mathrm{a}}-9^{\prime}$ and $\mathrm{H}-10$ ' were used to assign the $(R)$-configuration of the major enantiomer of 1 (Table S1). Therefore, the structure of 1 was assigned as $(R)-(-)-3-(8 '-$ hydroxy-3',7',11'-trimethyldodeca-2',6',10'-trienyl)-1H-indole with $33 \%$ ee.

All isolated compounds, except for compounds $\mathbf{4}$ and 7, which were not available in sufficient quantities, were evaluated for their antimalarial activities against Plasmodiam falciparum (TM4/8.2 and K1CB1) and cytotoxicities against human mouth epidermal carcinoma cells (KB) and Vero cells (Table S3). The farnesylindoles $\mathbf{1}$ and $\mathbf{2}$ exhibited significant but modest activities against the $P$. falciparum strains, which were much better than the flavonoid derivatives. Compound 2 had $\mathrm{IC}_{50}$ values of $27.9 \pm 2.57$ and $21.4 \pm$ $1.68 \mu \mathrm{M}$ against the TM4/8.2 and K1CB1 strains, respectively while compound 1 was slightly less active with $\mathrm{IC}_{50}$ values of $30.3 \pm 4.10$ and $25.1 \pm 1.61 \mu \mathrm{M}$, respectively. In terms of cytotoxicity, compound $1\left(\mathrm{IC}_{50}=22.3 \pm 0.39 \mu \mathrm{M}\right)$ displayed the highest activity against the KB cell line in comparison to the other isolated compounds. In addition, flavone 8 showed moderate activity against the TM4/8.2 and K1CB1 strains with $\mathrm{IC}_{50}$ values at $36.3 \pm 7.29$ and $27.2 \pm 6.20 \mu \mathrm{M}$, respectively. The tested compounds displayed little cytotoxicity against Vero cell with $\mathrm{IC}_{50}$ values $>50 \mu \mathrm{M}$ in these assays.

\section{Experimental}

For the details of the isolation of all compounds see the Supplementary material.

(R)-3-(8'-Hydroxyfarnesyl)-indole (1): yellow gum; $\alpha]_{D}^{27}$-6.9 (c $\left.0.15, \mathrm{CH}_{2} \mathrm{Cl}_{2}\right)$; UV $(\mathrm{MeOH}) \lambda_{\max }(\log \varepsilon): 222$ (4.3), $283(3.6) \mathrm{nm}$; IR (neat) $v: 3415,2924,1617 \mathrm{~cm}^{-1} ;{ }^{1} \mathrm{H}$ 
NMR (400 MHz, $\left.\mathrm{CDCl}_{3}\right): \delta_{\mathrm{H}} 7.60(d, J=7.8 \mathrm{~Hz}, 1 \mathrm{H}, \mathrm{H}-4), 7.35(d, J=7.8 \mathrm{~Hz}, 1 \mathrm{H}, \mathrm{H}-$ 7), $7.19(t, J=7.8 \mathrm{~Hz}, 1 \mathrm{H}, \mathrm{H}-6), 7.12$ ( $t, J=7.8 \mathrm{~Hz}, 1 \mathrm{H}, \mathrm{H}-5), 6.96$ ( $d, J=1.2 \mathrm{~Hz}, 1 \mathrm{H}$, H-2), $5.47\left(t, J=6.3 \mathrm{~Hz}, 1 \mathrm{H}, \mathrm{H}-2^{\prime}\right), 5.41\left(t, J=6.5 \mathrm{~Hz}, 1 \mathrm{H}, \mathrm{H}-6^{\prime}\right), 5.09(t, J=7.7 \mathrm{~Hz}$, 1H, H-10'), 3.97 (dd, J= $7.5 \& 5.8 \mathrm{~Hz}, 1 \mathrm{H}, \mathrm{H}-8$ '), 3.48 ( $\left.d, J=7.1 \mathrm{~Hz}, 2 \mathrm{H}, \mathrm{H}-1^{\prime}\right), 2.12-$ $2.29\left(m, 6 \mathrm{H}, \mathrm{H}-4^{\prime}, 5^{\prime}, 9^{\prime}\right), 1.78\left(s, 3 \mathrm{H}, \mathrm{H}-3{ }^{\prime} \mathrm{CH}_{3}\right), 1.72\left(s, 3 \mathrm{H}, \mathrm{H}-11^{\prime} \mathrm{CH}_{3}\right), 1.64(s, 3 \mathrm{H}, \mathrm{H}-$ 12'), $1.63\left(s, 3 \mathrm{H}, \mathrm{H}^{\prime} 7^{\prime} \mathrm{CH}_{3}\right) ;{ }^{13} \mathrm{C} \mathrm{NMR}\left(100 \mathrm{MHz}, \mathrm{CDCl}_{3}\right): \delta_{\mathrm{C}} 136.9$ (C-7'), $136.6(\mathrm{C}-8)$, 135.3 (C-3'), 134.8 (C-11'), 127.6 (C-9), 126.2 (C-6'), 123.4 (C-2'), 122.0 (C-6), 121.4 (C-2), 120.3 (C-10'), 119.2 (C-5), 119.1 (C-4), 116.0 (C-3), 111.2 (C-7), 77.4 (C-8'), 39.4 (C-4'), 34.3 (C-9'), 26.2 (C-5'), 26.0 (C-12'), 24.1 (C-1'), $18.1\left(\mathrm{C}-11^{\prime} \mathrm{CH}_{3}\right), 16.2\left(\mathrm{C}^{\prime} 3^{\prime} \mathrm{CH}_{3}\right)$, $11.8\left(\mathrm{C}^{-} 7^{\prime} \mathrm{CH}_{3}\right) ; \quad\left(\mathrm{HRESI}-\mathrm{MS} \mathrm{m} / \mathrm{z} \quad[\mathrm{M}+\mathrm{Na}]^{+} 360.2313\right.$ (calcd for $\mathrm{C}_{23} \mathrm{H}_{31} \mathrm{NONa}$, $360.2303)$ ).

\section{Conclusions}

A chemical investigation of the flower extracts of Anomianthus dulcis led to the isolation and identification of a new farnesylindole (1), which was a scalemic mixture (33\% ee), and nine known compounds (2-10). The farnesylindoles $\mathbf{1}$ - 2, and compounds 9 - 10 were discovered for the first time from this plant. The farnesylindoles $\mathbf{1}$ and $\mathbf{2}$ and flavone $\mathbf{8}$ showed moderate biological activity against the $P$. falciparum strains (TM4/8.2 and K1CB1). Furthermore, compound $\mathbf{1}$ also showed significant cytotoxicity against a KB cell line. None of these compounds were cytotoxic to Vero cells.

\section{Acknowledgements}

TP thanks the Science Achievement Scholarship of Thailand (SAST) and the Center of Excellence for Innovation in Chemistry (PERCH-CIC). We would like to thank Mr. Phorn Prommaharaj, Chiang Mai University, Thailand, for collecting the plant material. SK thanks NSTDA’s Cluster Program Management.

\section{Disclosure statement}

The authors declare no conflict of interest 


\section{References}

Auranwiwat C, Wongsomboon P, Thaima T, Rattanajak R, Kamchonwongpaisan S, Willis AC, Lie W, Pyne SG, Limtharakul T. 2017. 2-Phenylnapthalenes and a polyoxygenated cyclohexene from the stem and root extracts of Uvaria cherrevensis (Annonaceae). Fitoterapia. 120:103-107.

Auranwiwat C, Rattanajak R, Kamchonwongpaisan S, Laphookhieo S, Pyne SG, Limtharakul T. 2018. Four new C-benzyl flavonoids from the fruit of Uvaria cherrevensis. Fitoterapia. 130:198-202.

Auranwiwat C, Wongsomboon P, Thaima T, Rattanajak R, Kamchonwongpaisan S, Willis AC, Laphookhieo S, Pyne SG, Limtharakul T. 2019a. Polyoxygenated cyclohexenes and their chlorinated derivatives from the leaves of Uvaria cherrevensis. J Nat Prod. 82:101-110.

Auranwiwat C, Maccarone AT, Carroll AW, Rattanajak R, Kamchonwongpaisan S, Blanksby SJ, Pyne SG, Limtharakul T. 2019b. Structure elucidation of cyclohexene (9Z)-octadec-9-enyl ethers isolated from the leaves of Uvaria cherrevensis (Annonaceae). Tetrahedron. 75:2336-2342.

Awale S, Tawila AM, Dibwe DF, Ueda JY, Sun S, Athikomkulchai S, Balachandran C, Saiki I, Matsumoto K, Esumi H. 2017. Highly oxygenated antiausterity agents from the leaves of Uvaria dac. Bioorg Med Chem Lett. 27:1967-1971.

Benabderrahmane W, Amrani A, Benaissa O, Lores M, Lamas JP, Miguel TD, Benayache F, Benayache S. 2018. Chemical constituents, in vitro antioxidant and antimicrobial properties of ethyl acetate extract obtained from Cytisus triflorus 1'Her. Nat Prod Res. doi.org/10.1080/14786419.2018.1519816.

Chantrapromma K, Rat-A-pa Y, Karalai C, Lojanapiwatana V, Seechamnanturakit V. 2001. Corrigendum to "A chalcone and a dihydrochalcone from Uvaria dulcis" [Phytochemistry 53 (2000) 511-513]. Phytochemistry. 58:377.

Chou TH, Chen JJ, Lee SJ, Chiang MY, Yang CW, Chen IS. 2010. Cytotoxic flavonoids from the leaves of Cryptocarya chinensis. J Nat Prod. 73:1470-1475.

Ho DV, Kodama T, Le HTB, Phan KV, Do TT, Bui TH, Le AT, Win NN, Imagawa H, Ito T, Morita H, Nguyen HT. 2015. A new polyoxygenated cyclohexene and a new megastigmane glycoside from Uvaria grandiflora. Bioorg Med Chem Lett. 25:32463250 . 
Hsu YM, Wu TY, Du YC, El-Shazly M, Beerhues L, Thang TD, Luu HV, Hwang TL, Chang FR, Wu YC. 2016. 3-Methyl-4,5-dihydro-oxepine, polyoxygenated secocyclohexenes and cyclohexenes from Uvaria flexuosa and their anti-inflammatory activity. Phytochemistry. 122:184-192.

Jung MJ, Kang SS, Jung HA, Kim GJ, Choi JS. 2004. Isolation of flavonoids and a cerebroside from the stem bark of Albizzia julibrissin. Arch Pharm Res. 27:593-599.

Kadchumsang S, Sirisa-ard P., Sookkhee S, Chansakaow S. 2015. Antibacterial and antioxidant activities of Lanna medicinal plants used in Mahoog formula. Int J Pharm Pharm Sci. 7:366-370.

Kaweetripob W, Mahidol C, Prawat H, Ruchirawat S. 2015. Cyclohexene long-chain fatty acid esters from Uvaria dulcis (Dunal). Phytochemistry Lett. 12:248-251.

Liu RH, Wen XC, Shao F, Zhang PZ, Huang HL, Zhang S. 2016. Flavonoids from heartwood of Dalbergia cochinchinensis. Chin Herb Med. 8:89-93.

McNulty J, Nair JJ, Bollareddy E, Keskar K, Thorat A, Crankshaw DJ, Holloway AC, Khan G, Wright GD, Ejim L. 2009. Isolation of flavonoids from the heartwood and resin of Prunus avium and some preliminary biological investigations. Phytochemistry. 70:2040-2046.

Macabeo APG, Martinez FPA, Kurtán T, Tóth L, Mándi A, Schmidt S, Heilmann J, Alejandro GJD, Knorn M, Dahse HM, Franzblau SG. 2014. Tetrahydroxanthene1,3(2H)-dione derivatives from Uvaria valderramensis. J Nat Prod. 77:2711-2715.

Mfopa AN, Corona A, Eloh K, Tramontano E, Frau A, Boyom FF, Caboni P, Tocco G. 2017. Uvaria angolensis as a promising source of inhibitors of HIV-1 RT-associated RNA-dependent DNA polymerase and RNase H functions. Nat Prod Res. 32: 640647.

Nkunya MHH, Weenen H, Koyi NJ. 1987. 3-Farnesylindole from Uvaria pandensis VERDC. Phytochemistry. 26:2402-2403.

Nguyen TH, Ho VD, Do TT, Bui HT, Phan VK, Sak K, Raal A. 2015. A new lignan glycoside from the aerial parts and cytotoxic investigation of Uvaria rufa. Nat Prod Res. 29:247-252.

Ohtani I, Kusumi T, Kashman Y, Kakisawa H. 1991. High-field FT NMR application of Mosher's method. The absolute configuration of marine terpenoids. J Am Chem Soc. 113:4092-4096. 
Okpekon TA, Dade JME, Say MV, Yapo DK, Champy P, Séon-Méniel B, Yolou SF, Bories C. 2015. Bingervone, an antiprotozoal $\beta$-triketone derivative from the roots of Uvaria afzelii (Annonaceae). Int J Pharm Sci Res. 6:4210-4215.

Salae AW, Chairerk O, Sukkoet P, Chairat T, Prawat U, Tuntiwachwuttikul P, Chalermglin P, Ruchirawat S. 2017. Antiplasmodial dimeric chalcone derivatives from the roots of Uvaria siamensis. Phytochemistry. 135:135-143.

Sangster AW, Stuart KL. 1964. Ultraviolet spectra of alkaloids. Chem Rev. 65:69-130.

Sinz A, Matusch R, Witte L, Santisuk T, Chaichana S, Reutrakul V. 1998a. An Annonaceous acetogenin from the stem of Anomianthus dulcis. Biochem Syst Ecol. 26:361-362.

Sinz A, Matusch R, Witte L, Santisuk T, Chaichana S, Reutrakul V. 1998b. Alkaloids from Anomianthus dulcis. Biochem Syst Ecol. 26:139-141.

Sinz A, Matusch R, Elsäcker FV, Santisuk T, Chaichana S, Reutrakul V. 1999. Phenolic compounds from Anomianthus dulcis. Phytochemistry. 50:1069-1072.

Smitinand T. 2014. Thai plant names. Bangkok: The Forest Herbarium Royal Forest Department. p 574-575.

Sapchareun P. 2006. Sa Mun Prai Nai Auttayan Haeng Chat Pak Neu (in Thai). Bangkok: Sam Cha Reun. p 124.

Thomas PS, Essien EE. 2018. Antiglycation, antioxidant, and cytotoxic activities of Uvaria chamae root and essential oil composition. Nat Prod Res. doi.org/10.1080/14786419.2018.1504048

Tsukamoto S, Tomise K, Aburatani M, Onuki H, Hirorta H, Ishiharajima E, Ohta T. 2004. Isolation of cytochrome P450 inhibitors from strawberry fruit, Fragaria ananassa. J Nat Prod. 67:1839-1841.

Ubonopas L, Wongsinkongman P, Chuakul W, Suwanborirux K, Lee KH, Soonthornchareonnon N. 2014. Bioactive flavonoids and alkaloids from Anomianthus dulcis (Dunal) J. Sinclair stem bark. Mahidol University J Pharm Sci. 41:13-22.

Wada H, Tanaka N, Murakami T, Uchida T, Kozawa K, Saiki Y, Chen CM. 1988. Chemical and chemotaxonomical studies of filices. LXXVI. An unusual flavanone derivative from Wagneriopteris japonica LOEVE et LOEVE. Yakugaku Zasshi. 108:740-744. 
Wiya C, Saenphet K, Saenphet S, Buncharoen W. 2018. In vitro analysis of antispasmodic activity of ethanolic stem extracts of Uvaria rufa Blume and Anomianthus dulcis (Dunal) J. Sinclair on excised rat's ileum. 27:295-299.

Xia LZ, Zhou M, Xiao YH, Li GY, Chen XZ, Zhang GL. 2010. Chemical constituents from Helwingia japonica. Chin J Nat Med. 8:16-20. 


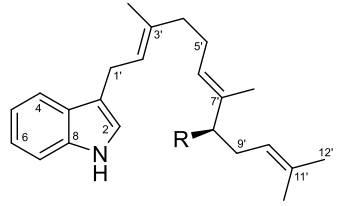

$1 \mathrm{R}=\mathrm{OH}: 33 \%$ ee

1a $\mathrm{R}=(S)$-MTPAO

1b $\mathrm{R}=(R)$-MTPAO

$2 \mathrm{R}=$<smiles>O=C1C[C@H](c2ccccc2)Oc2cc(O)cc(O)c21</smiles>

5<smiles>COc1cc(O)c2c(c1)O[C@@H](c1ccccc1)CC2=O</smiles>

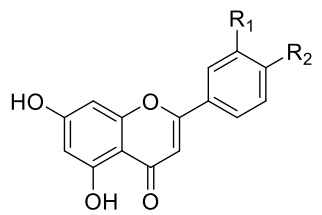
6: $R_{1}=R_{2}=H$
8: $R_{1}=R_{2}=O H$<smiles>COc1c(O)cc(O)c2c1O[C@H](c1ccccc1)CC2=O</smiles><smiles>O=C(/C=C/c1c(O)c(O)c(O)c(O)c1O)c1ccccc1</smiles>

7

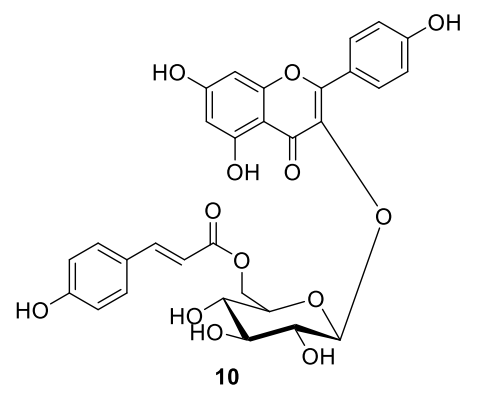

Figure 1. Structures of all isolated compounds (1-10). 